\title{
Okul Öncesi Dönemdeki Çocukların Eğitiminde Teknoloji Kullanımına İlişkin Öğretmen Görüşleri
}

\section{Teachers' Views on the Use of Technology in the Education of Preschool Children}

https://doi.org/10.52105/temelegitim.11.3

Tuğba AKSOY ${ }^{1}$

https://orcid.org/0000-0001-9352-7183

Geliş Tarihi/Received: 25/01/2021 Kabul Tarihi/Accepted: 30/06/2021 Yayın Tarihi/Published: 15/07/2021

\begin{abstract}
Özet: Bu çalışmada erken çocukluk döneminde eğitim veren öğretmenlerin, eğitimde teknoloji kullanımına ilişkin yönelik görüşleri; teknoloji kullanımını tercih edip etmedikleri, hangi teknolojik araçları kullandıkları ve teknolojinin etkili olduğunu düşünüp düşünmedikleri incelenmiştir. Çalışma 40 öğretmen üzerinden yapılmıştır. Bunların 1'i erkek, 39'u kadındır. Veri toplamak için 17 sorudan oluşan yarı yapılandırılmış görüşme formu kullanılmıştır. Katılımcı öğretmenlerin yarısından fazlasının teknolojik araç kullanımı eğitimi sahibi olduğu belirlenmiştir. Öğretmenlerin çoğu eğitimde teknoloji kullanımının gerekli olduğunu düşünmektedir. En çok kullanılan araçların bilgisayar ve projeksiyon, teknolojik araçlarla en çok yapılan etkinlikler ise çizgi film izletmek, dijital hikaye okumak ve müzik dinlemektir. Öğretmenlerin görüşlerine göre dil ve bilişsel gelişime katkı yapan teknolojik eğitim araç gereçleri aynı zamanda öğrenmeye ilgiyi arttırıp bilgilerin kalıcı olmasını sağlamaktadırlar. Ancak, bu şekilde öğrenmenin öğrencilerin sosyal ve duygusal gelişimine zarar verebileceğini düşünen öğretmenler de vardır.
\end{abstract}

Anahtar Kelimeler: Okul Öncesi, Teknoloji, Öğretmen Görüşleri

Abstract: In this study, the views of early childhood teachers on the use of technology in education; whether they prefer the use of technology, which technological tools they use, and whether they think technology is effective or not. The study was conducted on 40 teachers. 1 of them is male and 39 of them are female. A semi-structured interview form consisting of 17 questions was used to collect data. It was determined that more than half of the participating teachers had training in the use of technological tools. Most of the teachers think that the use of technology in education is necessary. The most used tools are computers and projections, and the most common activities with technological tools are watching cartoons, reading digital stories and listening to music. According to the opinions of the teachers, technological educational tools that contribute to language and cognitive development also increase the interest in learning and ensure that the information is permanent. However, there are also teachers who think that this way of learning can harm students' social and emotional development.

Keywords: Pre-School, Techonology, Teacher Opinions

Önerilen Atıf Bilgisi/To Cite This Article:Aksoy, T. .(2021). Okul Öncesi Dönemdeki Çocukların Eğitiminde Teknoloji Kullanımına İlişkin Öğretmen Görüşleri, Temel Eğitim Dergisi, 11, 30-38. https://doi.org/10.52105/temelegitim.11.3

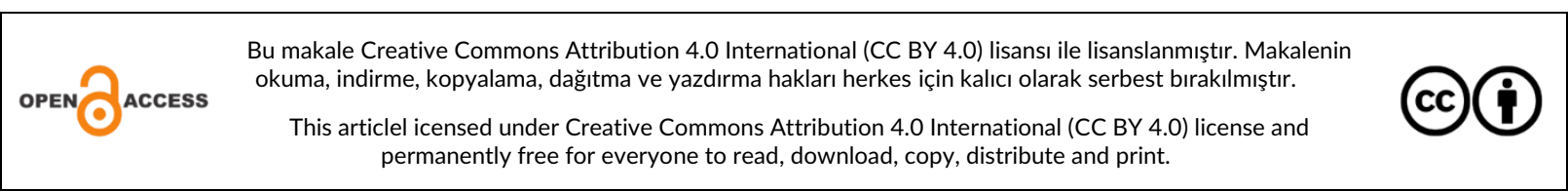

1. Giriş

Okul öncesi eğitim, ilköğretim, ortaöğretim ve yüksek ortaöğretim ile birlikte örgün eğitim sistemini oluşturan basamakların ilkidir. Çocukların ilk olarak 3-6 yaşları arasında adım attıkları bu basamak, ilköğretim sürecine geçene kadarki tecrübelerden oluşur ve ilköğretime hazırlanmaya yöneliktir. Bu dönemde kişilik de gelişir (Oktay, 2007). Bu dönemde çocuklar, bilişsel ve gelişimsel seviyeleri ile eşdeğer olarak yönlendirici eğitim alırlar (Oğuzkan \& Oral, 2003).

Erken çocukluk yılları, bireyin kişisel gelişiminde önemli bir dönemi kapsamaktadır. Kişinin kapasitesinin en yüksek seviyeye kadar gelebilmesi, erken yaşlarda sahip olduğu olanaklarla ilişkilidir. Bundan dolayı bireyin küçük yaşta içerisinde bulunduğu fiziksel ve sosyal ortam ve sahip olduğu imkânlar, o bireyin geleceğinde önemli rol

\footnotetext{
1 Tuğba Aksoy, tugbaerenaksoy@gmail.com
} 
oynamaktadır (Oktay, 2004). Yılmaz (2003), erken çocukluk eğitimini, 0-72 aylık çocukların, bütün gelişimlerini toplumsal değerler çerçevesinde yönlendiren, duygu ve algı güçlerini geliştirerek akıl yürütmelerine, yaratıcı olmalarına ve kendilerini ifade etmelerine destek olan, kendi fikirlerini ifade etmesine yardım eden ve öz denetim kazanmasını sağlayan, sistematik bir eğitim süreci olarak tanımlamaktadır. Poyraz ve Dere'ye (2001) göre erken çocukluk eğitimi, doğumdan itibaren ilköğretimin başlama dönemine kadar geçen yılları kapsayan, bu yaştaki çocukların fiziksel ve zihinsel gelişimini toplumun kültürel değerleri çerçevesinde destekleyen ve yönlendiren bir eğitimim sürecidir. Zembat (1992)'a göre ise okul öncesi eğitimi; doğumdan zorunlu eğitim hayatına başlayana kadar geçen dönemde çocukların gelişimlerini, karakter özellerini ve becerilerini göz önüna alarak onların fiziksel, duygusal, zihinsel ve sosyal olarak sağlıklı bir biçimde gelişmelerini sağlayan, olumlu kişisel özelliklerin yerleştirilmeye çalışıldığı, yaratıcılıklarının ve özgüvenlerinin desteklendiği ve okullar ile ailelerin işbirliği yaptığı sistemli bir eğitimdir.

Eğitim teknolojisi kavramı, teknolojinin eğitim sisteminin içine ilk olarak 1960'lı yıllarda entegre edilmesiyle ortaya çıkmıştır. Amerika Birleşik Devletleri'nde ortaya çıkan bu kavram, teknolojinin araç olarak kullanılmasından ziyade öğrenme sürecini desteklemesi için verdiği her türlü yardım anlamına gelmektedir. Eğitim teknolojisi, eğitimin verimliliğini arttırmak için yapılan girişimlerdir. Eğitim teknolojisinde hedef, var olan teknolojiyi eğitimin amaçlarına göre yönlendirmekten ziyade, eğitim taleplerinin teknolojideki gelişmelere göre ortaya konmasına yardımcı olmaktır. Teknolojinin hayatın her yerinde yaygınlaşması ile birlikte eğitimden uzak kalabileceği düşünülmemiş ve eğitime entegre edilmesiyle birçok olumlu sonuç elde edilmiştir (Bulun, Gülnar, \& Güran, 2004). Engler'e göre teknoloji, öğretimin vazgeçilmez bir unsurudur. Bu görüşünü şu şekilde ifade etmiştir. "Eğer eğitim her yönüyle öğretmen, öğrenci ve çevre arasında bir iletişim ağı olarak görülürse, o zaman öğretim teknolojisinin bu ilişkileri tanımlamada önemli bir görevi olduğu anlaşılabilir" (Akçay \& Özcebe, 2012, s. 69).

Okul öncesi eğitimde son dönemlerde bilgisayarlar tercih edilmektedir. İyi hazırlanan bir bilgisayarlı eğitim programı; çocukların zihinsel gelişimi, dil gelişimi, el becerilerinin gelişimi, sorun çözme yeteneklerinin gelişimi ve uzun süreli hafıza becerilerinin gelişmesine yardımcı olmaktadır. Bilgisayarlar sayesinde çocuklar daha yaratıcı ve eleştirel olabilmekte ve birbirleriyle daha rahat iletişim kurabilmektedirler. Böylece çocukların sosyal yönleri de gelişmektedir (Haughland, 2000; Parette, Hourcade \& Heiple, 2000). Levin, çocukların önemli bir kısmının uyku dışındaki öteki faaliyetlerin tümünden fazla teknolojiye zaman ayırdıklarını belirtmiştir (Levin, 2013). Guernsey (2012) de, 8 yaşından küçük çocukların yüzde elli ikisinin tablet, akıllı telefon yahut benzeri ürünleri kullanmakta olduğunu ifade etmiştir. Teknolojiden faydalanmak, yalnızca aynı gelişimsel etkiyi temin edecek öğrenme faaliyetine ulaşılabilecekse tavsiye edilmektedir (Palaiologou, 2014). Mesela, etkileşimli okuma yazma programları, okul öncesi çocuklara tekrar ve alıştırma biçimindeki önceki usullerin sunamadığı gelişmeyi sunmaktadır (Cordes \& Miller, 2000).

Bilgi ve İletişim Teknolojilerinin okul öncesi eğitimde kullanıyor olması, çocuklara birçok fayda sağlamaktadır. Özellikle çocuğun gelişim seviyesine ve belirlenen eğitim amaçlarına uygun olarak kullanılması durumunda gelişimine de olumlu etkiler yapmaktadır (Bütün \& Aral, 2005). Teknolojinin eğitim sürecine dâhil edilmesi ile ilgili yapılan çalışmalarda, çocuklar için öğrenmeyi daha keyifli hale getirdiği ve çocukların yaratıcı düşünme becerilerini geliştirdiği gözlenmektedir (Akpınar, 2005; Arı \& Bayhan, 2003; Sivin-Kachala \& Bialo, 2000). Teknolojinin faydalarının yanında, son yıllarda bilgi ve iletişim teknolojilerinin okullarda kullanılmasını destekleyenler ile birlikte bunun çocuklar için tehdit oluşturduğunu savunan bir kesim de mevcuttur. Cordes ve Miller (2000), okul öncesi dönemde çocukların teknolojik aletleri kullanıyor olmasının fiziksel, zihinsel, duygusal, sosyal ve ahlaki açıdan birtakım zararları olduğunu savunmaktadır. Televizyon, bilgisayar, tablet, cep telefonu gibi ekranlı aletleri çok yakından kullanan çocukların gözlerinde ve kötü duruşlarından dolayı omuriliklerinde sağlıksız durumlar oluşabileceğini belirtmişlerdir. Aynı zamanda bu çocuklarda duyu organı koordinasyonlarının geç gelişeceği de bu araştırmacılar tarafından belirtilen bazı risklerdendir.

TBM tarafından yayınlanan çalışmada (2016), teknolojinin kullanımının nasıl zararlı hale getirilebileceği açıklanmıştır: Kontrolsüz ve sınırsız kullanmak, gündelik hayattaki sorumlulukları aksatmak, uzun süreli ve uygunsuz içeriklerle kullanmak. Teknolojinin çocuğun sosyal ve duygusal gelişimine yararları (Akkoyunlu \& Tuğrul, 2002): Çocuğun motivasyonunu arttırması, Sorumluluk alma becerilerini geliştirmesi, İşbirliği ve paylaşımcı olmasını sağlaması, Bilgisayarda verilen işi bitirmekten keyif almaları, Daha girişimci olmalarına yardımcı olması olarak sıralanabilir. Teknolojinin çocuğun dil gelişimine yararları (Akkoyunlu \& Tuğrul, 2002): Uygun yazılımlarla çocukların daha uzun ve karmaşık cümleler kurabilmesine yardım etmesi, Daha akıcı konuşabilmelerini sağlama, Bilgisayarda yaptığı bir işi veya çizdiği bir resmi anlatmak isteyecek çocuğun konuşmasını sağlaması olarak özetlenebilir. Teknolojinin çocuğun psiko-motor gelişimine yararları (Akkoyunlu \& Tuğrul, 2002): Fareye tıklama, cd yerleştirme, göstergeci ekranda gezdirme gibi hareketler ile küçük kas gelişmeleri, Ekrandaki hareketleri izleyerek görsel beceri geliştirme gibi özelliklerdir. Teknolojinin çocuğun bilişsel gelişimine yararları (Akkoyunlu \& Tuğrul, 2002): Çocukların düşünme süreçlerini daha aktif kılmaları, Çocukların sanal dünyada gördüklerini yaratıcılıklarını kullanarak hayal etmeleri, Bilgisayarda verilen görevi yalnız yaparak özgüven geliştirme olarak sıralanabilir. Bilgisayar destekli eğitimler (İşman, 2001); Öğrencilerin konuları aktif bir şekilde öğrenmesini sağlar,, 
Ders içeriklerini kendi hızlarına göre takip etmelerine izin verir, Derse aktif katılımlarını sağlar, Eğitim etkinliklerinin kalitesini arttıır, Öğrenciye istediği kadar tekrar etme imkânı verir, Tablolar ve grafikler kolay bir şekilde oluşturulduğu için matematik ağırlıkı derslere ilgiyi arttıır, Öğrencilerin zamanını istedikleri gibi ayarlamasına izin verir, Kullanıcıya testler uygulayarak yeterliliğini sorgular, Kullanıcı ile ilgili bilgileri kaydederek öğrencinin kendi başarısını takip etmesine yardımcı olur.

Kaçar ve Doğan'a (2007) göre, bilgisayarın okul öncesi eğitime dâhil edilmesi, çocukların bir taraftan eğlenirken diğer taraftan öğrenmesine imkân vermektedir. Çocukların bir konuya odaklanıp keyif almasını sağlayan bilgisayarlar, çocuğun öğrenme başarısını ciddi oranda arttırmaktadır. Bilgisayar destekli eğitimde de çocuk bilgisayarı bir oyun aracı olarak gördüğü için çocukların eğitim becerilerine olumlu etki yapmaktadır. Ayrıca çocuklar, zihinsel gelişimlerine katkıda bulunduğunu hissettikleri bilgisayara daha olumlu düşüncelerle yaklaşarak ondan en yüksek düzeyde yararlanmaktadır. Given ve arkadaşları (2016), Avustralya'da yaşları 3 ile 5 arasında değişen 15 okul öncesi dönemdeki çocuğun, evde teknoloji kullanımlarını incelemiş ve bunun çocuklar üzerindeki etkilerini araştırmıştır. Araştırmada, çocukların evde teknolojik aletlerle anne babaları veya kardeşleri aracılığıyla, oyun veya iletişim gibi amaçlarla ilişkili olduğu görülmüştür. Çocukların dünyaları ile ilgili bilgi sahibi olmaya yardımcı olan bu gözlem döneminde, çocuklarının teknolojik aletlerle oynamalarının sosyal ve kültürel normları özümsediğine yardımcı olduğu ve çocukların bilgiye ulaşmasını kolaylaştırdığı tespit edilmiştir. Zomer (2014), 2004 ile 2014 yılları arasında yapılan ve 3 ile 6 yaş arasındaki çocukların teknoloji kullanımlarını araştıran çalışmaları incelemiştir. İncelenen 30 adet çalışma sonrasında, çalışmaların \%94'ünün, teknoloji kullanımının çocuklar üzerinde olumlu etkileri olduğunu belirttiği görülmüştür.

Babayiğit (2014), yaptığı çalışmada eğitim amaçlı bilgisayar oyunlarının okul öncesi eğitiminde kullanılması konusunda öğretmenlerin görüşlerini araştırmıştır. Ankara'da Milli Eğitim Bakanlığı'na bağlı olarak çalışan 142 öğretmenin örneklemi oluşturduğu çalışmada, okul öğrencisi öğretmenlerinin sınıftaki etkinliklerde bilgisayar oyunu tercih edip etmeme durumlarının yaşlarına, meslekteki kıdemlerine, öğrenim seviyelerine ve günlük hayatta bilgisayar oyunu oynayıp oynamadıklarına göre değişebildiği tespit edilmiştir. Bunun yanında, bilgisayar oyunları konusunda daha önceden eğitim alan öğretmenlerin, almayanlara oranla bu yöntemi daha çok tercih ettiği fark edilmiştir. Yaşı daha büyük olan öğretmenlerin genç öğretmenlere göre bilgisayar oyunlarını sıkıcı buldukları, sadece boş vakit değerlendirmek için tercih ettikleri ve çocuklar üzerinde kötü etkileri olabileceğini düşündükleri saptanmıştır. Gün içerisinde bilgisayar oyunu oynayan öğretmenlerin oynamayanlara göre ve lisans mezunu olan öğretmenlerin ön lisans mezunu olanlara göre, bu oyunların eğitim amacıyla çocuklara oynatılmasına daha sıcak baktıkları ve kendilerine daha çok güvendikleri görülmüştür.

Çağımızda teknoloji daha önceden tahmin edilemeyecek seviyelere gelmiştir. Bunun sonucu olarak bütün insanların hayatında teknoloji çok önemli yer kaplamaktadır. Hayat standardını arttııp yaşamı kolaylaştıran teknoloji bilgiye ulaşımı da kolaylaştırmaktadır. Bilgiye ulaşılabilecek alanlar giderek çeşitlenmiştir. Günümüzün çocukları teknolojinin bu kadar önemli olduğu bir dünyanın içine doğmuşlardır. Bu çocukların birçoğu akıllı telefon, bilgisayar ve tabletlere sahiptirler ve bunları sürekli kullanmaktadırlar. Dolayısıyla teknolojik uyaranlara tepki verir hale gelmişlerdir. Bu çocukların oynadıkları oyunlar, çevreleriyle iletişimleri ve sosyal yaşamları teknoloji çevresinde şekillenmiştir. Bu durum, okullarda verilen eğitimin bu araçları daha iyi eğitim verebilmek için kullanmasını zorunlu kılmıştır. Bu aynı zamanda bir fırsat olarak da değerlendirilmelidir.

Okul öncesi dönemdeki çocuklar çevreye karşı çok meraklı ve duyarlı oldukları bir çağ yaşamaktadırlar. Bu çocukların teknolojik cihazlara büyük ilgi göstermeleri son derece normaldir. Bilgisayarlar, tabletler ve akıllı telefonlar renkli, canlı ve hareketli ekranlarıyla bu çocukların ilgisini çekerler. Bunların interaktif yapısı da doğru ile yanlışa verdikleri tepkilerin ayarlanarak bir eğitim aracı haline getirilmelerini sağlamaktadır. Okul öncesi eğitimde teknoloji kullanımının dolayısıyla öğrencilerin derse ilgilerini, motivasyonlarını ve performanslarını arttıracağı açıktır.

Teknoloji ile öğrenmeye açık olan okul öncesi dönemindeki çocuklar bu şekilde öğrenmeye yönelmeleri için öğretmenlerinin onlara rehberlik etmesine ihtiyaçları vardır. Bunun gerçekleşmesi için öğretmenlerin yeterince kalifiye olması gerekmektedir. Ancak en az bunun kadar önemli bir husus da öğretmenlerin teknolojiye karşı tutumlarının olumlu olması gerekliliğidir. Okul öncesi öğretmenleri teknolojinin eğitimde fayda sağlayabileceğine inanmalıdırlar. Ayrıca okul öncesi eğitimde teknolojik cihazların ve yöntemlerin dizayn edilebilmesi için onları kullanacak öğretmenlerin görüşleri önem taşımaktadır. Dolayısıyla bu öğretmenlerin cihazlar ve yöntemler hakkında ne düşündükleri, hangilerini işlerinde kullandıkları ve hangilerini yararıı buldukları önem taşımaktadır. Bu çalışmada okul öncesi öğretmenlerinin teknoloji konusundaki tutumları; teknolojik araç kullanımının sağlıklı ve güvenli bulup bulmadıkları, çocukların öğrenme hızına etkisinin ne derece olduğu ve hangi gelişim alanlarına olumlu/olumsuz etki ettiği ile öğretmenlerin teknolojik araç kullanım süresi, sıklı̆̆ı, tercih ettikleri araç ve hangi etkinliklerde kullandıkları araştırılmıştır. 


\section{Yöntem}

\section{Araştırmanın Modeli}

Araştırma, genel tarama modellerinden tekil tarama modeli kesit alma yaklaşımı çerçevesinde betimleyici bir araştırma yöntemiyle tamamlanmıştır. Betimleyici araştırmalar; bir olay, durum ya da olguyu, olduğu biçimiyle inceleyip gözlemlemeyi ifade etmektedir. Bu araştırmada da, okul öncesi dönemdeki çocukların eğitiminde teknoloji kullanımına ilişkin öğretmen görüşleri, analiz edilmiş ve yorumlanmıştır.

\section{Çalışma Grubu}

Diyarbakır ili Bağlar ilçesinde görev yapan 39 kadın 1 erkek olmak üzere toplam 40 okul öncesi öğretmeni olarak belirlenmiştir. Öğretmenlerin $33^{\prime}$ 'ü anaokulu, 6'sı anasınıfı ve 1'i de uygulama sınıfında görev yapmaktadır. Öğretmenlerin 15'i 1-5 yıl arasında, 20'si 6-10 yıl, 5'i de 11 yıl ve üzeri kıdem yılına sahip olup 4'ü ön lisans, 34'ü lisans 2'si ise yüksek lisans mezunudur. 27 öğretmen teknolojik araç kullanımı ile ilgili eğitim almışken 13'ü almamıştır. Öğretmenlerin çalıştığı öğrenci yaş gruplarına bakıldığı zaman ise; 36-48 ay grubunda 7, 48-60 ay grubunda 20, 60-72 ay grubunda 9 ve karma yaş grubunda 4 öğretmen eğitim vermektedir. Çalışma grubu belirlenirken Bağlar ilçesini genellemek amacıyla tesadüfî örnekleme türlerinden basit rastgele yöntemi kullanılmıştır. Çalışma 2018-2019 eğitim öğretim yılında çevrimiçi görüşmeler yoluyla yapılmıştır. Öğretmenler önceden çalışma ile ilgili bilgilendirilmiş olup kişisel verilerinin hiç bir yerde açıkça paylaşılmayacağı bildirilmiştir.

Tablo 1. Kişisel Bilgilere İlişkin Frekans Analizi Sonuçları

\begin{tabular}{lll}
\hline & Frekans & Yüzde \\
\hline Cinsiyet & 39 & \\
Kadın & 1 & 97,5 \\
Erkek & \multicolumn{2}{c}{} \\
\hline Meslekteki kıdem yılı & 15 & 2,5 \\
$1-5$ yıl & 20 & 37,5 \\
$6-10$ yıl & 5 & 50,0 \\
11 yıl ve üzeri & & 12,5 \\
\hline Eğitim durumu & 4 & \\
Ön lisans mezunu & 34 & 10,0 \\
Lisans mezunu & 2 & 85,0 \\
Yüksek lisans mezunu & & 5,0 \\
\hline Çalısıllan okul türü & 33 & 82,5 \\
MEB'e bağlı anaokulu & 6 & 15,0 \\
MEB'e bağı anasınıfı & 1 & 2,5 \\
MEB' bağı uygulama sınıfı & & \\
\hline Teknolojik araç kullanımı ile ilgili eğitim alma durumu & 27 & 67,5 \\
Evet & 13 & 32,5 \\
Hayır & & \\
\hline Eğitim verilen çocukların yaş grubu aralığı & 7 & 17,4 \\
36-48 ay & 20 & 50,0 \\
$48-60$ ay & 9 & 22,5 \\
60-72 ay & 4 & 10,0 \\
Karma yaş grubu & & \\
\hline
\end{tabular}

\section{Veri Toplama Araçları}

Araştırmada veri toplama amacıyla yarı yapılandırılmış görüşme formu kullanılmıştır. Görüşme formu alan yazın taraması yapıldıktan sonra oluşturulmuştur. Form uzman görüşüne sunulmuş olup düzeltmeler yapılarak son şekli verilmiştir. Form 17 sorudan oluşmaktadır. Formda demografik bilgiler(cinsiyet, yaş, kıdem yıllı, eğitim durumu), öğretmenin çalıştığı okul türü-yaş grubu, teknolojik araç kullanımı konusunda eğitim alıp almadıkları, sınıfta ne sıklıkla, hangi amaçla ne kadar süre ile hangi tür etkinlikte teknolojik araç kullandıklarını ve hangi araçları tercih ettikleri bu kullanım sonrası ise çocukların hangi gelişim alanlarını olumlu/olumsuz etkilediği, sağlıklı ve güvenli olup olmadığı ve çocukların öğrenme hızına etkisi sorulmuştur. Veriler, görüntülü sesli uygulama üzerinden çevrimiçi gerçekleştirilmiş olup öğretmenler öncelikle bilgilendirilmiştir. Ortalama olarak $40 \mathrm{dk}$ süren görüşmeler bilgisayar ortamına kayıt edilmiş olup sadece bu çalışma için kullanılmıştır. Etik kurallar çerçevesinde öğretmenlerin kişisel bilgilerine yer verilmemiş olup öğretmen görüşleri "Ö" harfi ile gösterilerek görüşmedeki sıraya göre numaralandırılmıştır.(Ö1, Ö2 gibi.) 


\section{Verilerin Analizi}

Görüşme sonucu elde edilen bilgiler yazılı olarak kayıt altına alındıktan sonra nicel veriler IBM SPSS 20 programında analiz edilmiştir. Öğretmenlerin kişisel bilgilerine ilişkin elde edilen bulgular analiz edildikten sonra teknolojik araç kullanımı ile ilgili sorulan sorulara verilen cevaplar incelenerek içerik analizi yapılmıştır ve program analizindeki sonuçlarla birlikte yorumlanmıştır. Bu çalışma alanyazında okul öncesi öğretmenlerinin teknoloji kullanımına yönelik bakış açılarını tespit etmek amacıyla hem nicel hem de nitel yaklaşım kullanılarak hazırlanmıştır.

\section{Bulgular}

Tablo 2. Eğitimde Teknolojik Araç Kullanımına İlişkin Frekans Analizi Sonuçları

\begin{tabular}{|c|c|c|}
\hline 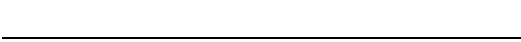 & Frekans & Yüzde \\
\hline \multicolumn{3}{|c|}{$\begin{array}{l}\text { Okul öncesi dönemdeki çocukların eğitiminde teknolojik araçlar (tablet, dizüstü } \\
\text { gisayar vb.) kullanılmalı mıdır? }\end{array}$} \\
\hline Evet & 33 & 82,5 \\
\hline Hayır & 7 & 17,5 \\
\hline \multicolumn{3}{|c|}{ Sınıfınızda teknolojiyi ne sıklıkla kullanırsınız? } \\
\hline Hiç kullanmam & 1 & 2,5 \\
\hline Nadiren kullanırım & 17 & 42,5 \\
\hline Her gün kullanırım & 22 & 55,0 \\
\hline \multicolumn{3}{|c|}{ Eğer kullanıyorsanız aşağıdaki teknolojik araçlardan hangilerini tercih ediyorsunuz? } \\
\hline Televizyon & 4 & 10,0 \\
\hline Bilgisayar & 28 & 70,0 \\
\hline Projeksiyon & 31 & 77,5 \\
\hline Akıllı Tahta & 7 & 17,5 \\
\hline \multicolumn{3}{|c|}{ Sınıfta teknolojik araçları ne amaçla kullanırsınız? } \\
\hline Çocuklara çizgi film izletmek için & 19 & 47,5 \\
\hline Çocuklara müzik dinletmek için & 27 & 67,5 \\
\hline Çocuklara dijital hikâye okumak için & 19 & 47,5 \\
\hline Diğer & 18 & 45,0 \\
\hline \multicolumn{3}{|c|}{ Sınıfta teknolojik araçları (tablet, dizüstü bilgisayar vb.) kullanma süreniz nedir? } \\
\hline 5-20 dakika & 15 & 62,5 \\
\hline 20-40 dakika & 25 & 37,5 \\
\hline \multicolumn{3}{|c|}{ Günlük planlarınızda teknolojiyi hangi tür etkinliklerinizde kullanıyorsunuz? } \\
\hline Oyun etkinliği & 28 & 70,0 \\
\hline Müzik etkinliği & 36 & 90,0 \\
\hline Türkçe-dil etkinliği & 28 & 70,0 \\
\hline Matematik etkinliği & 14 & 35,0 \\
\hline Sanat etkinliği & 8 & 20,0 \\
\hline Fen etkinliği & 12 & 30,0 \\
\hline \multicolumn{3}{|c|}{ Sınıfta teknolojik araçları çocuklar kullanabiliyor mu? } \\
\hline Evet & 8 & 20,0 \\
\hline Hayır & 32 & 80,0 \\
\hline
\end{tabular}

Eğitimde teknolojik araç kullanımına ilişkin frekans analizi sonuçları incelendiğinde öğretmenlerin \%82,5'inin okul öncesi dönemdeki çocukların eğitiminde teknolojik araçların kullanılması gerektiğini düşündüğü bulunmuştur. Öğretmenlerin \%2,5'i sınıfta teknoloji hiç kullanmadığını belirtirken, \%42,5'i nadiren, \%55'i ise her gün kullandığını belirtmiştir. Teknolojik araç olarak televizyon öğretmenlerin \%10'u tarafından tercih edilirken, bilgisayar \%70'i tarafından, projeksiyon \%77,5'i tarafından, akıllı tahta ise \%17,5'i tarafından tercih edilmektedir. Öğretmenlerin \%47,5'i teknolojik araçları sınıfta çocuklara çizgi film izletmek için, \%67,5'i müzik dinletmek için, \%47,5'i dijital hikâye okumak için, \%45'i ise diğer amaçlara yönelik kullandığını belirtmiştir. Öğretmenlerin \%62,5'i sınıfta teknolojik araçları 5-20 dakika süreyle kullandığını belirtirken, \%37,5'i 20-40 dakika arası süreyle kullandığını belirtmiştir. Öğretmenlerin \%70'i günlük planlarında teknolojiyi oyun etkinliği için kullanırken, \%90'ı müzik etkinliği, \%70'i Türkçe-dil etkinliği, \%35'i matematik etkinliği, \%20'si sanat etkinliği, \%30'u ise fen etkinliği için kullandığını belirtmiştir. Sınıfların \%20'sinde çocuklar teknolojik araçları kullanabilirken, \%80'inde kullanamamaktadır.

Tablo 3. Eğitimde Teknolojik Araç Kullanımında Öğretmen Görüşlerine İlişkin Frekans Analizi Sonuçları

\begin{tabular}{lcc}
\hline & Frekans & Yüzde \\
\hline Teknoloji ile eğitimin, çocukların hangi gelişim alanlarını desteklediğini düşünüyorsunuz? & & \\
Motor gelişimi & 11 & 27,5 \\
Dil gelişimi & 33 & 82,5
\end{tabular}




\begin{tabular}{|c|c|c|}
\hline $\begin{array}{l}\text { Sosyal-duygusal gelişim } \\
\text { Öz bakım becerileri } \\
\text { Bilişsel gelişim }\end{array}$ & $\begin{array}{l}19 \\
6 \\
30\end{array}$ & $\begin{array}{l}47,5 \\
15,0 \\
75,0\end{array}$ \\
\hline $\begin{array}{l}\text { Teknoloji ile eğitimin, } \\
\text { işünüyorsunuz? }\end{array}$ & & \\
\hline Motor gelişimi & 6 & 15,0 \\
\hline Dil gelişimi & 3 & 7,5 \\
\hline Sosyal-duygusal gelişim & 22 & 55,0 \\
\hline Öz bakım becerileri & 3 & 7,5 \\
\hline Bilişsel gelişim & 6 & 15,0 \\
\hline
\end{tabular}

Eğitimde teknolojik araç kullanımında öğretmenlerin görüşlerine ilişkin frekans analizi sonuçları incelendiğinde öğretmenlerin \%27,5'i teknoloji ile eğitimin çocukların motor gelişimini desteklediğini düşünürken, \%82,5'i dil gelişimini, $\% 47,5^{\prime} \mathrm{i}$ sosyal-duygusal gelişimini, $\% 15^{\prime} \mathrm{i}$ öz bakım becerilerini, $\% 75^{\prime} \mathrm{i}$ ise bilişsel gelişimini desteklediğini düşünmektedir. Öte yandan, öğretmenlerin \%15'i teknoloji ile eğitimin çocukların motor gelişimini olumsuz etkilediğini düşünürken, \%7,5'i dil gelişimini, \%55'i sosyal-duygusal gelişimini, \%7,5'i öz bakım becerilerini, \%15'i ise bilişsel gelişimini olumsuz etkilediğini düşünmektedir.

Araştırmada bunun yanı sıra öğretmenlere okul öncesi dönemindeki çocukların eğitiminde teknoloji kullanımını sağlıklı ve güvenli bulup bulmadıkları ve teknoloji kullanımının çocukların öğrenme hızına olan etkileri sorulmuştur.

Elde edilen cevaplar incelendiğinde öğretmenlerin büyük çoğunluğu teknoloji çağında olduğumuzdan dolayı çocukların teknolojiden uzak kalmamaları gerektiğini, teknoloji kullanımının çocuğun eğitime katkı sağladığını, eğitici videolar, görsel ve işitsel materyallerin çocukların gelişimini desteklediğini düşünmektedir.( Ö6:Amacımız eğitim olduğu sürece kullanılmasını sağlıklı ve güvenli buluyorum. Teknoloji hayatımızın içinde olduğu için kesin bir şekilde çocukların uzak tutulmasını doğru bulmuyorum. Ö7:Evet. Endüstri 4.0'ı yaşadığımız bugünlerde çocuklarımızın teknolojiden geri kalmamaları gerektiğini düşünüyorum. Ö9:Artık bilgi çağındayız ve bilgiler çok hızı değişip yenilenebiliyor. Okul öncesi dönemde de teknoloji kullanılmalı ki öğrenciler bu hızlı değişimden mahrum kalmasınlar. Ö31:En aktif öğrendikleri bir dönem bir yetişkin denetiminde belli bir süre olması çağın gerisinde kalmamak adına olabilir. Ancak böyle güvenli kullanım sağlanabilir. Ö34:Çağ gereği kullamaları gerektiğine inanıyorum ama kontrollü bir şekilde.)

Öte yandan öğretmenler, teknoloji kullanımının öğretmen kontrolünde olması gerektiğini, çocukların bu konuda serbest bırakılmaması gerektiğini düşündüklerini belirtmişlerdir.( Ö4:Veli ve oğretmen kontrolünde olduğu sürece sağlıklı ve güvenli olduğunu düsünüyorum. Ö11:Evet, öğretmen gözetiminde planlı bir şekilde kullanıldığında yararlı olur. Ö17:Kontrol edilebilmesi ve ne sıklıkta kullanıldı̆̆ı önemli. Ö19:Teknoloji çağında olmamızdan kaynaklı çocukları bu alandan uzaklaştırmayı sağlıksız buluyorum. Kullanım alanı öğretmen tarafından kontrollü ve dozunda kullanılırsa çok daha sağlıklı olacağına inanıyorum. Ö24:Öğretmen kontrollü ve sınırı sürede kullanıldığında olabilir. Ö27:Doğru ve süreli kullanımı öğrenme hızını destekleyebilir ama bunun çok iyi kontrol edilmesi gerekli. Ö40:Öğretmenin denetiminde olduğu sürece sorun olmaz. Çocukları görsel olarak destekleme amaçlı kullanımında sakınca yoktur.)

Teknoloji kullanımının çocukların öğrenme hızına olan etkileri incelendiğinde ise öğretmenler görsel ve işitsel materyallerle desteklenen eğitimin hafızada daha çok kaldığını ve bu durumun öğrenme hızını olumlu etkilediğinden bahsetmiştir. (Ö3:Günümüzdeki sınıf ortamları düşünüldüğünde, teknoloji kullanımı gerçek hayatla daha somut bağlantı sağlayabileceği için ve uyaranları arttırdığı icin öğrenme hızını etkileyebilir.)

Ayrıca teknolojik araçların çocukların ilgisini daha çok çektiği için daha hızlı ve sıkılmadan öğrenmeyi sağladığını belirtmişlerdir.(Ö3:Çağımızın getirdiği teknolojiyi, teknolojik aletler çocukların dikkatini bu kadar çekebiliyorken, etkili ve verimli bir şekilde (sesli kitap, eğitici video, şarkı vb.) gerektiği miktarda kullanılıyor ise sağlıklı ve güvenli buluyorum. Ö16:Kesinlikle etkiler. Çocukların ekrana karşı dikkatleri ve ilgileri uyanık olduğundan hızlıca kapabiliyorlar. Ekranda izledikleriyle daha çok eğleniyorlar bu da hem eğlenmesine hem de öğrenmesine yol açıyor.)

Genel olarak görsellikten kaynaklı olarak çocukların daha hızlı ve daha kalıcı öğrendiği öne sürülmüştür. (Ö1:Görsellik sunduğu için kalıcılık sağlıyor. Ö2: Evet, etkiler görseller ve tekrar etme imkânı sunduğu için çocukların aklında daha kalıcı olduğunu düşünüyorum. Ö6:Evet, olumlu yönde etkiler. Görsel, işitsel uyaranları bir arada sunduğu için çocukların dikkatini daha çok çeker ve katılımı artıır. Ö33:Evet, görsellik de işin içine girdiği için anlamlı öğrenme ve dolayısıyla hızı anlamalarını sağlıyor.)

Öte yandan öğretmenler, teknoloji kullanımının çocukların öğrenme hızını olumlu etkilemesi için teknolojinin çocuklara faydalı olacak eğitici içeriklere sahip olması gerektiğini belirtmişlerdir. Çocuklara vakit geçirme amaçlı sunulan çizgi film benzeri içeriklerin faydadan çok zararı olabileceğinden bahsedilmiştir. (Ö14:Eğer faydalı bilgi veriliyorsa öğrenme hızını olumlu yönde etkiler. Fakat çizgi film gibi gereksiz amacı olmayan görseller izlettirilmesinin faydasından çok zararı olmaktadır. Çocuklara evde yeterince çizgi film izlettiriliyor. Ö37: Amacına uygun kullanılırsa tabiki sağlıklı ve güvenilir bulurum. Ben günlük olarak ele alacağım kavram veya nesne veya özel 
bir günse (belirli gün ve haftalarla ilgili) kahvaltı saatimizden önce konuyla ilgili kısa bir video izletirim. Kahvaltıdan sonra konumuzu hatırlayıp etkinligimizi yaparız. Eğer varsa konuyla ilgili interaktif oyun oynatıım. Ama teknolojiyi sadece zaman geçirmek çocukları oyalamak için kullanırsam tabiki de bu sağlıklı ve güvenilir bir kullanma olmaz.)

Öğretmenler, teknoloji ile eğitimin çocukların en çok dil ve bilişsel gelişimine etki edeceğini düşünürken, sosyal ve duygusal gelişim açısından da olumsuz etkileyebileceğini düşündüklerini belirtmişlerdir. (Ö5:Çoğunlukla sağlıksız olduğunu düşünüyorum. Görerek ve dokunarak öğrenmenin daha etkili olacağı kanaatindeyim. Ö8:Bilişsel gelişimi destekler. Ö13:Sağlıklı bulmuyorum. Ö22:Sağlıksız buluyorum. Sosyal ve duygusal açıdan olumsuz etkileniyorlar ayrıca dil gelişimi olarak da teknolojik dil yapısı oluşuyor. Ö25: Evet teknoloji kullanımı gerekli. Yapılan etkinliğin birden fazla gelişim alanına hitap etmesini sağlar. Özellikle bilişsel ve dil alanın gelişmesini sağlar. Ö27:Hayır bulmuyorum dil sosyal ve bedensel gelişimin çok hızlı olduğu bu dönemde fazla teknoloji kullanımı çocukları daha az sosyal ve daha bağımlı yapıyor. Ö28:Hayır. Çünkü bireysel farklılıklar gözetilmeden sunulan teknoloji kullanımının çocuklarda olumsuz etkileri söz konusu olabiliyor. Ö31:Sürekli aynı şeyler izleyip yapmak monotonluk durağanlığa neden olabilir fakat farklı değişken eğitici öğretici yenilikçi etkinlikler özellikle dil ve bilişsel gelişimi destekleyebilir.)

\section{Tartışma ve Sonuç}

Araştırma sonucunda elde edilen bulgular incelendiğinde katılımcı öğretmenlerin yarısından fazlasının teknolojik araç kullanımı ile ilgili eğitim aldıkları görülmüştür. Öğretmenlerin büyük çoğunluğu okul öncesi dönemdeki çocukların eğitiminde teknolojik araçların kullanılması gerektiğini düşünmektedir. Teknolojik araç kullanımında genellikle bilgisayar ve projeksiyonun tercih edildiği görülürken, bu teknolojik araçlar genellikle çocuklara müzik dinletmek için kullanılmakta, bunun yanı sıra çizgi film izletmek ve dijital hikâye okumak için de kullanılmaktadır. Öğretmenlerin yarıya yakını ise teknolojik araçları hem eğitim amaçlı hem de diğer amaçlar için kullandı̆̆ını belirtmiştir. Sınıfta teknolojik araçların kullanımının 40 dakikayı geçmediği görülmektedir. Günlük planlarda ise öğretmenlerin teknolojiyi genellikle müzik, oyun ve Türkçe-dil etkinliklerinde kullandığı görülmektedir. Bunların yanı sıra sınıfların büyük çoğunluğunda teknolojik araçları çocuğun kullanmadığı, bu araçların öğretmen kontrolünde olduğu bulunmuştur. Öğretmenler, teknoloji ile eğitimin çocukların en çok dil ve bilişsel gelişimine etki edeceğini düşünürken, sosyal ve duygusal gelişim açısından da olumsuz etkileyebileceğini düşündüklerini belirtmişlerdir. Ayrıca öğretmenlerin, öğretmen kontrolünde olduğu sürece çocukların eğitiminde teknoloji kullanımının sağlıklı ve güvenli bulduğu tespit edilmiştir. Bunlara ek olarak öğretmenler, eğitici amaçla kullanıldığı sürece teknolojik araç kullanımının görsel ve işitsel materyal bolluğundan dolayı çocukların öğrenme hızını artıracağını ve bu şekilde öğrenmenin daha eğlenceli ve kalııı olacağını düşünmektedirler.

Erdoğan (2009), yaptığı araştırmada okul öncesi dönemdeki çocuklar için satranç eğitiminde geleneksel ve bilgisayar bazlı öğrenme tekniklerini karşılaştırmıştır. Konya'da toplam 40 anasınıfı öğrencisinin örneklemi oluşturduğu çalışmada, bilgisayar destekli öğrenme yöntemlerinin uygulandığı öğrencilerin geleneksel yöntemlerle satranç öğrenen öğrencilere göre daha başarılı oldukları tespit edilmiştir. İstatistiklerin yanı sıra bilgisayar ile satranç öğrenen öğrencilerin derslere daha severek katıldığı ve daha keyifli zaman geçirdikleri gözlenmiştir. Satranç öğrenmenin en çok bilişsel gelişimi ilgilendirdiği düşünüldüğünde, çalışmamızda yer alan öğretmenlerin bilgisayarlı eğitimin bilişsel becerileri geliştireceği yönündeki görüşleri ile benzerlik göstermektedir.

Tekcan (2009), öğrenme hızının en yüksek olduğu 3-6 yaş arasındaki çocukların fiziksel, zihinsel ve sosyal gelişimleri için kabul edilen pedagojik yaklaşımların bilgisayar destekli okul öncesi eğitiminde çocukların Türk milli unsurlarını kullanımını araştırmıştır. Bu dönemdeki çocukların öğrenmesinin en hızı oyunlarla gerçekleşeceğini belirten Tekcan, bu oyunların çocuklar üzerindeki olumlu ve olumsuz etkilerini de incelemiştir. Araştırmanın sonucunda, okul öncesi eğitiminde bilgisayar kullanımının çocuk eğitimine büyük katkısı olduğu, bilgisayar destekli uygun eğitim programlarının geliştirilebileceği belirtilmiş ve bir tasarı oluşturulmuştur. Tasarıda, Türk kültürünün en önemli ögelerinden olan Nasreddin Hoca ve Keloğlan ile ilgili bilgisayar destekli görselleştirme ve animasyonların çocuklar üzerinde daha kalıcı etkiler bıraktığı görülmüştür. Tekcan'ın öğrenmenin kalıcı olduğunu göstermesi çalışmamıza katılan öğretmenlerin görüşleriyle uyum içerisindedir; öğretmenler bilgisayar aracılığı ile görsel ve işitsel materyaller kullanılması öğrenilenlerin kalıcı olmasına katkı sağladığını düşünmektedirler.

Çakmaz (2010), yaptığı araştırmada okul öncesi öğretmenlerin eğitim teknolojilerini kullanma durumlarını çalışmıştır. Bu kapsamda Bolu ilindeki okul öncesi kurumlarda görev yapan 75 adet öğretmen örneklemi oluşturmuştur. Araştırma sonucunda öğretmenlerin eğitim teknolojilerini kullanmada yaşları ve eğitim seviyelerinin anlamlı bir fark yaratmadığı ancak hizmet yılının anlamlı değişiklikler yarattığı görülmüştür. Ayrıca öğretmenlerin teknolojik cihazlar hakkında eğitim almalarının, kullanımlarını etkilediği de belirlenmiştir. Okul öncesi öğretmenlerinin ilan panosu, teyp, televizyonu kullandıkları ancak anlamlı bir çoğunluğunun film şerit makinesi, epidiaskop ve elmoyu bilmedikleri ve okulda bulunmadığı için haberdar olmadıkları tespit edilmiştir. Öğretmenlerin genel olarak halen geleneksel yöntemleri tercih ettiği ve kitap, grafikler, maketler, büyük resimler, vcd, cd'ler ve ilan panolarını kullandıkları görülmüştür. Araştırmamızdaki öğretmenlerden benzer sonuçlar 
alınmamıştır; en çok kullanılan cihazlardan biri bilgisayar olmuştur ancak burada bilgisayara vurgu yapılmamıştır. Televizyonun ve projeksiyon kullanılması ise bu çalışmayla uyum göstermektedir.

Yüksel (2011), doktora tezinde dijital öykü anlatımının okul öncesi eğitim kurumlarında nasıl işlendiğini araştırmıştır. Çağımızda bilgisayarın eğitim aşamalarında sıklıkla kullanılan bir araç olması, çocuklara yararı ve zararlarını, eğitmenler tarafından nasıl kullanıldığını ve eğitim sistemine nasıl entegre edilmesi gerektiğini tartışıır hale getirmiştir. Araştırmada, daha önce dijital öykü hazırlama seminerine katılan okul öncesi öğretmenler örneklem olarak kullanılmıştır ve onların tecrübeleri ele alınmıştır. Bunun yanı sıra öğretmenlerin bu teknolojileri kullanırken yaşadığı zorluklar da incelenmiştir. Ortalama 20 öğrencileri bulunan 5 adet okul öncesi öğretmeninin bu teknolojiyi kullanımına dair örnekler veren çalışmada, çocuklar için kritik olan okul öncesi eğitiminde teknolojiden verimli bir şekilde yararlanmanın önemine dikkat çekilmektedir.

Çankaya (2012), okul öncesi eğitimi gören öğrencilerin birtakım matematik kavramlarını öğrenmesinde bilgisayar oyunlarının etkisini araştırmıştır. Araştırmada, Erzurum ilinde bir anasınıfında eğitim gören öğrenciler örneklem olarak kullanılmıştır. Deneysel yöntemin izlendiği çalışmada, öğrencilere kavramlar öğretilmiş, daha sonra deney grubuna bilgisayar oyunlarıyla, kontrol grubuna da geleneksel oyunlarla pekiştirme yapılmıştır. Eğitimlerin sonunda uygulanan son testlerde bilgisayar oyunları ile desteklenen grubun, geleneksel oyunlar ile uygulama yapılan gruptan anlamlı bir şekilde daha başarılı olduğu görülmüştür. Çalışmadan beş hafta sonra yapılan kalıclık testinde ise yine bilgisayar oyunları ile eğitilen çocukların daha başarılı olduğu tespit edilmiştir. Bu çalışma, hem başarının hem kalıcı öğrenmenin bilgisayar destekli eğitim ile arttığını göstermekte ve araştırmamıza katılan öğretmenlerin görüşleri ile benzemektedir.

Küçükoğlu (2013), yüksek lisans çalışmasında 4-5 yaşındaki okul öncesi öğrencilerinin bilişsel gelişimlerini dikkate alarak renk kavramını öğrenmelerine veya pekiştirmelerine yardımcı olması için Dick, Carey ve Carey modelinden yola çıkarak bilgisayar destekli bir tasarı geliştirmiştir. Çocuklara sunulan bu tasarım sonrasında, bilgisayar ortamında sunulacak öğretilerin çocukların ve eğitimcilerin önerileriyle geliştirilmesinin önemi ortaya çıkmıştır. Bu tasarının, çocukların bilişsel gelişimlerine ve öğretmenleri ile anne babalarına çocuğa renk kavramlarını öğretme konusunda başarılı olduğu düşünülmektedir. Küçükoğlu'nun çalışması da öğrencilerin bilişsel gelişimlerinin eğitimde bilgisayar kullanımından olumlu etkilendiğini belirtmiştir ve bulguları bu çalışma ile uyum içerisindedir.

Köroğlu (2014), okul öncesi öğretmenlerin ve öğretmen adaylarının bilişim teknolojileri öz yeterlilik algıları, teknolojik araç gereç kullanım tutumları ve bireysel yenilikçilik düzeyleri arasındaki ilişkileri incelemiştir. Araştırmanın çalışma grubu Karaman ilinde Milli Eğitim Bakanlığı'na bağlı okul öncesi kurumlarda çalışan 100 adet öğretmen ve Konya'da okul öncesi öğretmenliği konusunda eğitim almakta olan 100 adet son sınıf öğrencisi yer almıştır. Araştırmanın sonucuna göre, okul öncesi öğretmenlerin bilişim teknolojileri öz yeterlilik algıları ve teknolojik araç gereç kullanım tutumlarının yüksek olduğu, bireysel yenilikçilik düzeylerinin "öncü" seviyesinde yüksek olduğu tespit edilmiştir. Öğretmen adaylarının ise bilişim teknolojileri öz yeterlilik algıları ve teknolojik araç gereç kullanım tutumlarının yüksek olduğu ve "sorgulayıcı" seviyesinde orta düzeyde yenilikçi olduğu saptanmıştır. Araştırmamızda da aynı şekilde öğretmenlerin teknolojik araç gereçleri eğitimde kullanmaya hevesli oldukları görülmüştür.

Hsin ve arkadaşları (2014), okul öncesi eğitimde çocukların teknoloji kullanımının faydalarını araştıran çalışmaları incelemişlerdir. Bu konuda 2003 ve 2013 yılları arasında yapılan bilimsel çalışmaları inceleyen araştırmacılar, çalışmaların çoğunluğunda, teknoloji kullanımının çocukların eğitimlerine ve gelişmelerine olumlu etkilerinin olduğunu tespit etmişlerdir. Çalışmalarda, teknolojinin çocukların ilişkilerine ve işbirliği yeteneklerine katkıda yaptığı görülmüş, çeşitliliği desteklediği saptanmıştır. Bu çalışmanın teknoloji kullanımının eğitime katkı sağladığı kısmında beyan edilen görüş araştırmamıza katılan öğretmenlerce paylaşılmakla beraber, teknoloji kullanımının sosyal ve duygusal gelişim açısından zararlı olabileceği görüşünün bu çalışma tarafından desteklenmediği görülmektedir.

Çocuğa küçük yaşlarda sunulacak tecrübeler ile kazanılacak temel alışkanlık, yetenek ve bilgiler, çocuğa ilerleyen eğitim hayatı ile birlikte duygusal ve toplumsal hayatında da farkındalık sağlayacak niteliktedir. Şansa bırakılamayacak kadar önemli; sistematik ve bilimsel bir yapı ile idare edilmesi gereken okul öncesi öğretim, bütün eğitim sisteminin en önemli parçasıdır (Arı, 2005). Bununla beraber okul öncesi eğitim; çocuğun ilerleyen hayatındaki eğitiminin temelini atarak, çocuğun pozitif karakter özelliklerine sahip olması, alışkanlık, değer yargıları, tavır ve inançlarının belirginleşmesi, ebeveynin çocuğun öğretiminde role sahip olması eğitimin istikrarının tesisi bakımından büyük öneme sahip bir süreçtir (Zembat, 1992). Okul öncesi eğitim, çocuğun gelişimine katkı sağlaması; ebeveynlerin sunamadığı eğitim imkânlarından faydalanabilmesini, ebeveynlerin çocuk eğitimi ile alakalı bilinçlendirilmesini sağlamaktadır (Oktay, 2007).

Çocuk; yardımlaşmayı, dayanışmayı, paylaşmayı, iş bölümünü, takım çalışmasını, diğer kişilere saygı göstermeyi, kendini korumayı, dinlemeyi, zamanı verimli kullanmayı, planlı ve programlı davranmayı, sorumluluk almayı ve daha birçok alışkanlığı okul öncesi eğitim kurumlarında daha etkin şekilde öğrenmektedir. 
Okul öncesi dönemindeki çocukların gelişimlerine katkı sağlayacak mahiyette ve gelişim seviyelerine uygun araçlara başvurulması oldukça önemlidir. Bu araçların çocukların eğitimine yardımcı olacak ve somut nitelikli olmaları gerekmektedir. Okul öncesi eğitim faaliyetlerinde yararlanılan araçların çocuk odaklı, kavram gelişimine yardımcı olan ve soyut kavramlara somut nitelik kazandırabilecek imkânda tasarlanmış olması gerekmektedir. Çocukların gelişimine yardımcı olacak araçlar arasında teknolojik araçlar da sayılabilir.

\section{Kaynakça}

Akçay, D., \& Özcebe, H. (2012). Okul Öncesi Eğitim Alan Çocukların ve Ailelerinin Bilgisayar Oyunu Oynama Alışkanlıklarının Değerlendirilmesi. Çocuk Dergisi, 12(2), 66-71.

Akkoyunlu, B., \& Tuğrul, B. (2002). Okulöncesi Çocukların Ev Yaşantısındaki Teknolojik Etkileşimlerin Bilgisayar Okuryazarlığı Becerileri Üzerindeki Etkisi. Hacettepe Üniversitesi Eğitim Fakültesi Dergisi, 23, 12-21.

Akpınar, Y. (2005). Bilgisayar Destekli Eğitimde Uygulamalar. Ankara: Anı Yayıncılık.

Arı, M. (2005). Erken çocukluk eğitimi ve kalitenin önemi. M. Sevinç içinde, Erken çocuklukta gelişim ve eğitimde yeni yaklaşımlar (s. 31-35). İstanbul: Morpa Kültür Yayınları.

Arı, M., \& Bayhan, P. (2003). Okul Öncesi Dönemde Bilgisayar Destekli Eğitim. Ankara: Epsilon Yayınları. Bütün, A., \& Aral, N. (2005). Bilimsel Araştırma ve Incelemeler. Ankara: A.Ü. Ev Ekonomisi Yüksekokulu Yayını.

Babayiğit, Ö. CC. (2014). Eğitim Amaçıı Bilgisayar Oyunlarının Okul Öncesi Eğitimde Kullanımına Yönelik Öğretmen Görüşleri: Ankara ilii Örneği. Yüksek Lisans Tezi. Gazi Üniversitesi Eğitim Bilimleri Enstitüsü .

Bulun, M., Gülnar, B., \& Güran, M. S. (2004). Eğitimde Mobil Teknolojiler. The Turkish Online Journal of Educational

Technology, 3(2), 23.

Cordes, C., \& Miller, E. (2000). Fool's Gold: A Critical Look at Computers In Childhood.

http://www.allianceforchildhood.net/projects/computers/computers_reports.htm adresinden alındı

Çakmaz, B. (2010). Okul Öncesi Öğretmenlerinin Eğitim Teknolojilerini Kullanma Durumlarının İncelenmesi (Bolu ili

Örneği). Yüksek Lisans Tezi. Abant İzzet Baysal Üniversitesi Sosyal Bilimler Enstitüsü.

Çankaya, Ö. (2012). Bilgisayar Oyunlarıın Okul Öncesi Eğitiminde Kullanılmasının Bazı Matematiksel Kavramların

Öğretimi Üzerine Etkisi. Yüksek Lisans Tezi. Atatürk Üniversitesi Eğitim Bilimleri Enstitüsü.

Erdoğan, İ. (2009). Okulöncesi Dönemde Satranç Öğretiminde Geleneksel ve Bilgisayar Destekli Öğretim Yöntemlerinin

Karşılaştırılması. Yüksek Lisans Tezi. Selçuk Üniversitesi Sosyal Bilimler Enstitüsü.

Given, L. M., Winkler, D. C., Wilson, R., Davidson, C., Danby, S., \& Thorpe, K. (2016). Watching Young Children "Play" With

Information Technology: Everyday Life Information Seeking in the Home. Library \& Information Science Research, 38(4), 344352.

Hsin, C. T., Li, M. C., \& Tsai, C. C. (2014). The Influence of Young Children's Use of Technology on Their Learning: A

Review. Journal of Educational Technology \& Society, 17(4), 85-99.

İşman, A. (2001). Bilgisayar ve Egitim. Sakarya Üniversitesi Egitim Fakültesi Dergisi(2).

Köroğlu, A. Y. (2014). Okul Öncesi Öğretmenlerinin ve Öğretmen Adaylarının Bilişim Teknolojileri Özyeterlik Algıları,

Teknolojik Araç Gereç Kullanım Tutumları ve Bireysel Yenilikçilik Düzeylerinin İncelenmesi . Yüksek Lisans Tezi. Gazi

Üniversitesi Eğitim Bilimleri Enstitüsü.

Küçükoğlu, B. (2013). Okul Öncesi Eğitimine Yönelik Bilgisayar Destekli Öğretim Tasarımı. Yüksek Lisans Tezi. Bahçeşehir

Üniversitesi Fen Bilimleri Enstitüsü .

Kaçar, A. Ö., \& Doğan, N. (2007). Okulöncesi Eğitimde Bilgisayar Destekli Eğitimin Rolü. Akademik Bilişim, 1-11.

Levin, D. E. (2013). Beyond remote-controlled childhood: Teaching young children in the media age. Washington: National

Association for the Education of Young Children.

Oktay, A. (2004). Yaşamın Sihirli Yılları: Okul Öncesi Dönem. İstanbul: Epsilon Yayınları.

Oktay, A. (2007). Okul Öncesi Eğitimin Önemi Ve Yaygınlaştırılması. A. Oktay, \& Ö. P. Unutkan içinde, Okul Öncesi Eğitimde

Güncel Konular. İstanbul: Morpa Yayınları.

Oğuzkan, Ş., \& Oral, G. (2003). Kız Sanat Okulları Için Okulöncesi Eğitimi. İstanbul: MEB.

Palaiologou, I. (2014). Children Under Five And Digital Technologies: Implications For Early Years Pedagogy. European

Early Childhood Education Research Journal , 24(1).

Parette, H. P., Hourcade, J. J., \& Heiple, G. S. (2000). Computers And Young Children. The Important Of Structured

Computer Experiences For Young Children With And Without Disabilities. Early Childhood Education Journal, 4(27), 243-250. Poyraz, H., \& Dere, H. (2001). Okul Öncesi Eğitimin ilke ve Yöntemleri. Ankara: Anı Yayıncılık.

Sivin-Kachala, J., \& Bialo, E. R. (2000). Research Report on the Effectiveness of Technology in Schools. Washington, DC:

Software and Information Industry Association.

TBM. (2016). Teknolojiye Yerinde Yeterince. Türkiye Bağımlııkla Mücadele Eğitim Programı. İstanbul: Kültür Sanat Basımevi. Tekcan, A. (2009). Bilgisayar Destekli Okul Öncesi Eğitimde Milli Öğelerin Kullanımı ve Bir Etkileşimli Eğitim Tasarımı.

Yayınlanmamış Yüksek Lisans Tezi. Sakarya Üniversitesi Sosyal Bilimler Enstitüsü.

Yüksel, P. (2011). Using Digital Storytelling In Early Childhood Education: A Phenomenological Study Of Teachers'

Experiences. Doktora Tezi. Orta Doğu Teknik Üniversitesi Fen Bilimleri Enstitüsü .

Yılmaz, D. (2003). Türkiye 'de Okul Öncesi Eğitimi, Gelişim ve Eğitimde Yeni Yaklaşımlar. (M. Sevinç, Dü.) İstanbul: Morpa

Yayınları.

Zembat, R. (1992). Okul Öncesi Eğilim Kurumları'nda Yönetim ve Yönetici Özellikleri. Yayınlanmamış Doktora Tezi. Marmara

Üniversitesi Sosyal Bilimler Enstitüsü.

Zomer, R. N. (2014). Technology Use in Early Childhood Education: A Review of the Literature. Yüksek Lisans Tezi. UOIT. 